\title{
Green Economy's Prospects in Russia: Case of Baikal Area
}

\author{
Alla A. Pakina \\ Department of Environmental Management, \\ Lomonosov Moscow State University, Moscow, Russian Federation \\ e-mail: allapa@yandex.ru
}

Cite as: Pakina, A. A., Green Economy's Prospects in Russia: Case of Baikal Area, J. sustain. dev. energy water environ. syst., 2(2), pp 139-151, 2014, DOI: http://dx.doi.org/10.13044/j.sdewes.2014.02.0013

\begin{abstract}
Transition to a green economy is one of key directions of Russian modernisation. According to the "eastern vector" of the Russian economy, principles of a green development are crucial for regions of Eastern Siberia, one of which is the Baikal area. Actual directions of economic activities are a mining industry on a base of polymetallic ore fields, and a touristic industry in a frame of Special Economic Zone "Baikal haven". Economic growth is a necessary condition for improvement of living standards of the local population, but environmental and economic indicators of these development directions differ considerably. Transition from traditional economic indicators, oriented on consumption, to effective development, focused on preserving of ecological services of natural landscapes, is one of the most important issues of green economy in a practice. This article considers perspective directions of economic development within the Republic of Buryatia as a part of the Baikal Natural Area, and evaluates possibilities of transition to a green economy.
\end{abstract}

\section{KEYWORDS}

Green economy, Baikal area, Environmental services, Economic growth, Renewable resources

\section{INTRODUCTION}

Transition to a green economy was proclaimed by the Russian government as a major idea of national economy's modernisation. It is widely known that the Russian economy has actually a raw orientation, and fully depending on extraction of non-renewable resources, such as oil and natural gas. This hampers to improvement of environment state, both in industrially developed regions, and in areas of new development: large territories in a mining areas require rehabilitation due to high level of pollution and a growing amount of industrial waste; the threat of water areas' pollution is increasing due to offshore gas and oil extraction, particularly in northern and eastern seas; forests' area is declining, what contribute to global climate changes. Total annual economic damage as a result of environmental degradations in Russia reaches 4-6\% of GDP [1].

Principles of a green economy, including its environmental, economic, social, technological, moral and ethical aspects were considered in many works [2-4]. According to [3], idea of "green" economy reformulated the concept of "demand and supply", focusing not on consumption, but on its efficiency. The effectiveness of nature goods conservation in a frame of a regional ecological-economic analysis was reviewed in [5] and further developed by many other authors [6-8].

According to the definition, formulated by experts of United Nations Environment Program (UNEP), "green" economy" is an economy that "results in improved human well-being and social equity, while significantly reducing environmental risks and 
ecological scarcities". In other words, a green economy can be thought as a low-carbon, resource efficient and socially inclusive economy. All these principles are extremely important for actual development of the eastern regions of Russia, but the greatest attention must be given to development of innovative technological and management approaches. Innovations, which demands technical change adapted to a new market structure, are probably the most important benefit from environmentally oriented policies [9]. The quest for new technologies and processes contribute not only to improvement of environmental situation, but also increases the demand for skilled labour [10]. The article considers perspectives of the "green" economy in Republic of Buryatia on a base of integrated approach with attention to social, economic, ecological and geographical factors.

\section{INSTITUTIONAL PREREQUISITS OF TRANSITION TO A GREEN ECONOMY IN RUSSIA}

Actually green economy's issues are equally important both for a scientific community and political authorities in Russia. In order to improve ecological situation and to provide economic and social stability in the country, there was adopted a number of relevant policy documents, oriented on needs of greening economy: "Principles of state policy in the field of environmental development of Russia until 2030" (approved by the President of the Russian Federation on April 30, 2012), the National Program "Environment Protection" of the Russian Federation on period of 2012-2020 and others. According to the "eastern vector" of modern Russian economy, principles of green economy are crucial for regions of Eastern Siberia, and especially for the Baikal area with its high ecological value of a pristine wilderness. Environmental issues of the area are particularly considered in the State Program of Development the Far East and Baikal Area up to 2025 and the Federal Target Program "Protection of the Lake Baikal and a social and economic development of the Baikal Natural Area on 2012-2020".

Special attention to Baikal area is also fixed in a special part of the National Program "Environment Protection": "Problem of the Lake Baikal". At one of the first positions among "expected results of the program" there is "an effective system of state regulation and control in a field of environmental protection and ecological safety, encouraging a modernization of the economy, based on principles of a "green growth" [11]. Along with this, the Program focuses on conditions for an involvement of eco-efficient innovations, development of a market of environmental goods and services, and attention to environmental safety for the population. One of the indicators of a "green growth" at the Baikal region, fully corresponding to the best international experience - building conditions for a "green jobs" [12]. The understanding of an importance of "green" criteria of a quality of life is demonstrated in quantitative indicators of the Program, such as: reduction of emissions from stationary sources per unit of GDP by 2.2 times; improvement in environmental conditions of life for 36 million Russians, living in unfavourable environment; a growth of the share of the territories, occupied by protected areas up to $13.5 \%$ of the country - a level corresponding to the best international standards. Thus, greening of the Russian economy is a key direction of state development for the period of the next decades. Unfortunately, a real economic situation at the Eastern Siberia, including the Baikal Area, does not correspond to a line of greening - as well as in Russia in general. Current economic development is based on the use of fossil fuels with a minimum share of renewable sources, and development indicators are far from socially oriented ones.

Declared rate of GDP growth was not met in 2012: instead 3.5\% the growth was fixed at the level of $3.4 \%$ (compared to $4.3 \%$ in 2011) [13]. Unfortunately, the rate of GDP growth expected in 2013 was not also reached: a real rate was $2.4 \%$ instead $3.6 \%$ that were planned 
in a beginning of 2013. Thus, Russian economy is characterized by contradictory trends: a need for growth, as a prerequisite of social stability at the regions, on the one hand, and a need to move towards a green economy - on the other. Experiences of developed countries show that these conflicting trends may well be combined with each other. The situation can be considered as an advantage, since it is possible to use the most advanced technologies, according to the latest trends. This approach to development is consistent to the objectives of the programs mentioned above: to focus on the best world practices in order to achieve accelerated economic development.

\section{BAIKAL AREA AS AN ARENA OF ACTIONS}

Challenges for a green economy we consider by the example of extremely interesting region of Eastern Siberia - the Baikal Natural Area, which lies in a frame of three large regions of the Russian Federation: Irkutsk district, Republic of Buryatia and a Zabaikalskiy region (Fig. 1). Current situation and perspectives of economic development at the Baikal area we studied during the field trips to the Republic of Buryatia at 2012-2013. The area is featured by extremely rich mineral resources, huge territory, harsh climatic conditions and low density of population. The core of the area - Lake Baikal - is globally known by its ecological value, pristine wilderness and huge resources of fresh water with unique hydro-chemical characteristics. Due to these features the lake with its surrounding territories got a status of the World Heritage Site.

Lake Baikal is one of the oldest lakes in the world, the age of which scientists determine as 25-30 million years. The lake has a greatest depth $(1,637 \mathrm{~m})$ among the lakes of the world, its surface's area is $31,500 \mathrm{~km}^{2}$. Baikal is also the largest repository of fresh water on the planet with 23 thousand $\mathrm{km}^{3}$. Around 140 thousand people consider the lakeside of Baikal as their home, and about one million people - its basin. All types of human activity at BNA are limited by Federal Law "On Protection of the Lake Baikal", and have to be regulated by state ecological expertise.

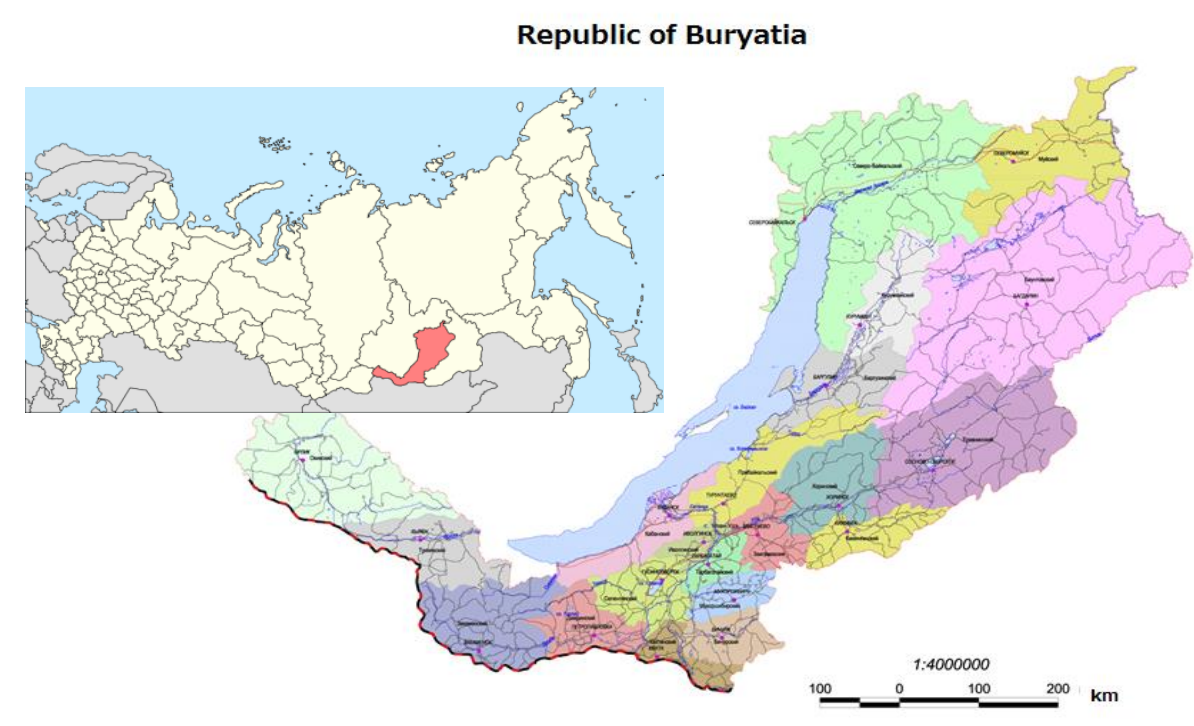

Figure 1. Administrative map of the Republic of Buryatia (with inset map of Russia) [14]

Total area of the Republic of Buryatia, including water area, is 351.3 thousand $\mathrm{km}^{2}$, which is comparable to the area of Germany (357 thousand $\mathrm{km}^{2}$ ), or Finland (337 thousand $\mathrm{km}^{2}$ ). Number of population is 971.8 thousand people (2013), population density -2.77 people per $\mathrm{km}^{2}$ [13]. If to compare it with European countries - Finland, for example, which 
is more close to Buryatia by features of nature - we will get value over 5 times more - about 5.4 million people, and a population density 16 people $/ \mathrm{km}^{2}$. Economic indicators are also significantly different with European developed countries: GDP is 136.4 billion Russian roubles (RR) (2010) or $\$ 4.27$ billion, per capita - 132.1 thousand RR or $\$ 4.13$ thousand (for comparison: $\$ 3.089$ trillion or $\$ 37.8$ thousand in Germany and $\$ 185$ billion or $\$ 34.4$ thousand in Finland respectively).

Table 1. Republic of Buryatia in economy of Russia (2013)

\begin{tabular}{lccc}
\hline & $\begin{array}{c}\text { Republic of } \\
\text { Buryatia (RB) }\end{array}$ & $\begin{array}{c}\text { Russian } \\
\text { Federation (RF) }\end{array}$ & $\begin{array}{c}\text { Share of RB } \\
\text { in RF, [\%] }\end{array}$ \\
\hline Area, thousand $\mathrm{km}^{2}$ & 351.3 & $17,098.2$ & 2.0 \\
Population, thousand people & 971.8 & 142,009 & 0.7 \\
$\begin{array}{l}\text { GDP, billion RR (2010) } \\
\text { The volume of industrial }\end{array}$ & 136.4 & $44,516.0$ & 0.3 \\
production, bn RR (2008) & 29.3 & 11,209 & 0.3 \\
\hline
\end{tabular}

Obviously, economic growth is necessary for the republic. Priority measures for economic development were elaborated in the various programs adopted in Buryatia in the last years. Basis of these measures is the development of transportation infrastructure and water and gas supply. Since there is no own resource base of natural gas in the Republic of Buryatia, gasification is based on liquefied gas. The overall level of gasification with liquefied gas is still very low - about $15 \%$. Poor infrastructure, along with harsh natural conditions, is a major obstacle to economic development.

However, a substantial economic growth is planned for the next 20 years in the Republic. Development of a mineral resources sector and a tourism industry are selected as the development priorities for the future. Unfortunately, the development of these industries is often not consistent with the requirements of a green economy, being associated with high environmental risk. The most obvious potential risks for green growth - as well as economic growth at all - are associated primarily with the development of polymetallic ore fields the Ozernoye and the Kholodninskoye. Thus, a mining industry, based on rich polymetallic ore fields, is a key sector of further economic development, through which it is planned to raise GDP and living standards in Buryatia (Fig. 2).

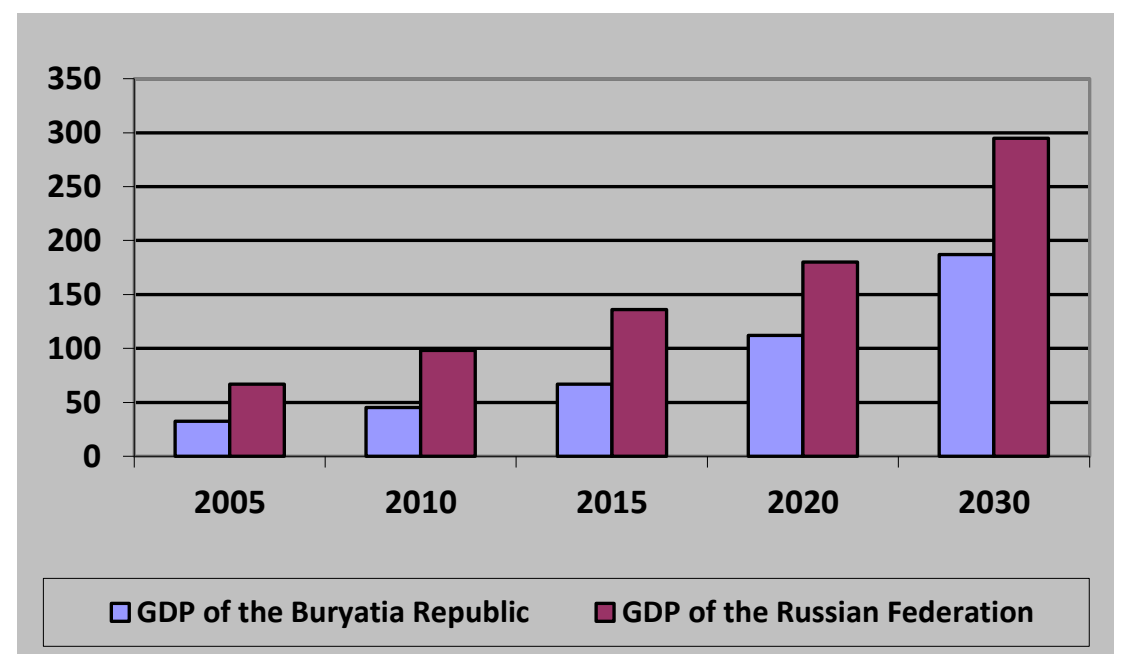

Figure 2. GDP of the Republic of Buryatia (blue column) and of the Russian Federation (purple column), thousand RR per person per year [15] 
Along with the mentioned above natural and infrastructure obstacles to economic growth, an important factor of environmental management in the region is the presence of special territorial unit - the Baikal Natural Area (BNA). Federal law "On Protection of the Lake Baikal" establishes severe restrictions for all the types of activities within the BNA.

Baikal Natural Area is legislatively defined area of $386,000 \mathrm{~km}^{2}$, which includes Lake Baikal, the water protection zone, its basin within the boundaries of the Russian Federation, protected natural areas near Lake Baikal, and the area up to $200 \mathrm{~km}$ wide, adjacent to the lake from west and north-west sides. In order to protect the unique natural site, a special system of environmental management was elaborated for the area. There are three ecological zones within BNA: 1) central zone; 2) buffer zone and 3) ecological zone of atmospheric impact (Fig. 3; the ecological zones are marked by red, green and blue colour respectively). The most stringent restrictions are set for the Central Ecological Zone (CEZ), where any economic activities, that may harm the Lake Baikal ecosystems, are prohibited. Due to the huge area of BNA, we examined potential risks and prospects of green economic development within the boundaries of the Republic of Buryatia.

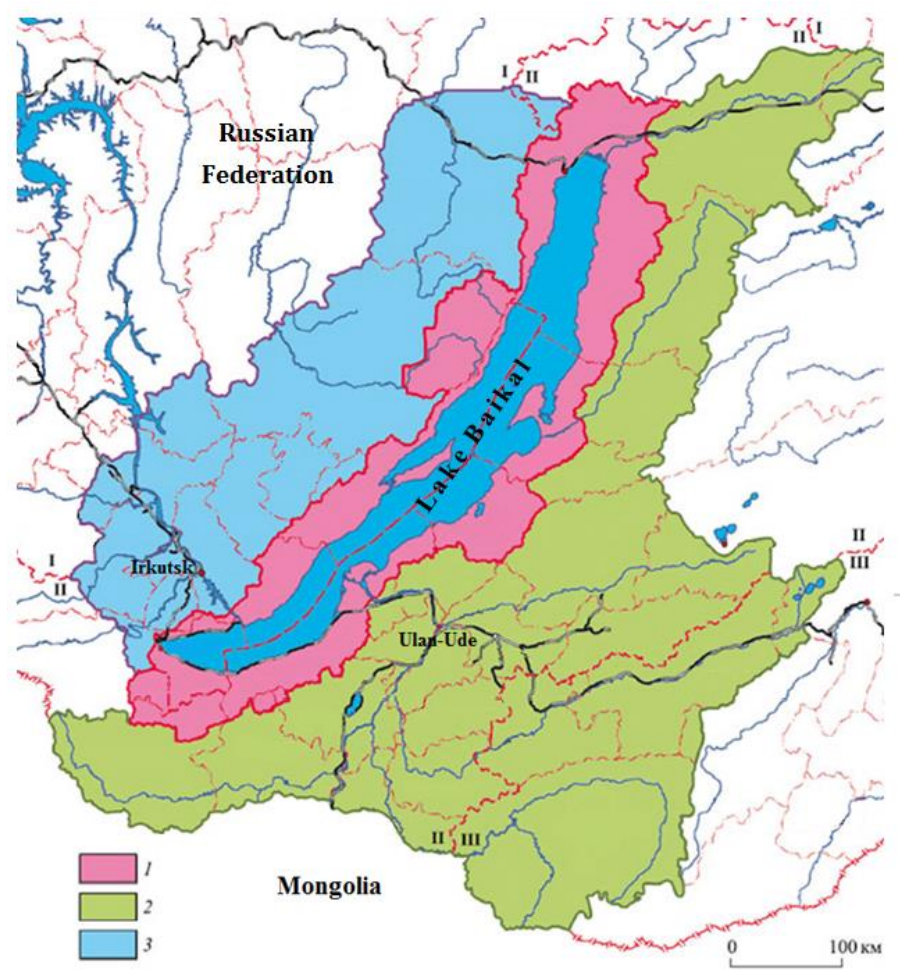

Figure 3. Baikal Natural Area [16]

\section{ECONOMIC GROWTH AND ENVIRONMENT}

\section{Current environmental risk factors}

Despite a low rate of economic growth in Buryatia, there is a number of strong risk' factors, affecting both on natural landscapes and their components, and on the Baikal water quality. Analysis of distribution of polluting emissions within the BNA shows that the main volume of pollution comes from the territory of the Irkutsk region. Large number of industrial polluters are located at Angarsk and Irkutsk cities at the Angara river - the only river, flowing out of the Baikal Lake (Fig. 3). But the major environmental risk during many years was caused by Baikalsk' Pulp and Paper Mill (BPPM), located at the south western 
part of Baikal. BPPM until 2007 was the main polluter of the Lake Baikal. According to the State Report "On the state of the Lake Baikal and the measures for its protection in 2008", the volume of emissions at the period from 1999 to 2008, when the plant was running at full capacity, was about 45 million tons per year. In contrast to other polluters BPPM supplied its emissions directly into the Central Ecological Zone of BNA. Only in 2013 there was accepted the decision of the Russian Governance to stop the plant.

Angarsk and Irkutsk cities are also producers of a large volume of pollution and are included in the list of most polluted Russian cities. For example, in 2011 in Irkutsk was fixed 13-fold excess of the maximum permissible concentrations of benzo(a)pyrene, as well as the excess of $\mathrm{NO}_{2}$, formaldehyde and suspended solids [17]. The largest share in the total emissions of Angarsk city falls on thermal power (over 60\%) and petroleum industries. Most of the pollution is transported over long distances, threatening BNA. A significant contribution to the pollution of the area make the industries of Buryatia, located in Ulan-Ude and Gusinoozersk - coal thermal power plants, machine-building plants, coal mining, etc. The main feature of the impact on environment in the area is a prevailing role of thermal power plant: they throw out about $50 \%$ of all air emissions. Fortunately, there are grounds to say about total emissions reducing not only in the last years (25.5 thousand tons less in 2011), but also about common tendency: reducing on 34\% during period 2007-2011. Despite these encouraging findings, the total air emissions in the frame of BNA in 2011 amounted to 375.4 thousand tons, discharges into water bodies -400.4 million $\mathrm{m}^{3}$, and the total volume of industrial waste has achieved 10,845.5 thousand tons [16].

Plans for economic development of Buryatia, including the living standards' raise, focused mainly on expanded use of raw material base, where the key point is development of the Ore Mining and Processing Enterprise "Ozernoye". Great expectations are associated with rich reserves of polymetallic ores, as well as with agreements reached on its development. Ozernoye field is the second one by reserves of zinc in Russia (after the field Kholodninskoe at the northern part of Buryatia) and the eighth in the world, and belongs to the category "large" according to world standards. Total ore reserves at the field are estimated at 157 million tons, and projected capacities allow to mine about 8 million tons of ore annually, and produce 740 tons of zinc concentrate and 110 tons of lead concentrate [18]. The field is located in Yeravna region - administrative unit of the Republic of Buryatia with an area of $30,000 \mathrm{~km}^{2}$ and population about 18,000 people. The area is located in a permafrost zone with high coefficient of weather's harshness, weak transportation infrastructure and large distances from cities Ulan-Ude and Chita - of 300 and $170 \mathrm{~km}$ respectively. The deposit is located within Vitimsky plateau, on the border of taiga and vast hollows, occupied by Eravninsky lakes. Permafrost have a continuous distribution throughout the area, its depth varies from 15 to $150 \mathrm{~m}$. At the same time, an important advantage of the Ozernoye field is its location out of BNA unlike Kholodninskoye field, which is located in immediate vicinity of Lake Baikal, within Central Ecological Zone.

It is assumed that all works will be carried out according to the principle of public-private partnership: investments will be made by the state and regional governments, and the holder of the license to develop the field - the corporation "Metals of Eastern Siberia". Field development project includes the development of infrastructure: local railways and roads, transmission and electricity supply facilities, system of water supply and sewage, etc. In the long term there can be formed a cluster, containing a number of mining and processing plants, forming a necessary base for the economic stability and population well-being. In a case of implementation of these plans, investment in the region could reach \$3.3 billion [19]. However, one of the most important consequences of the Ozernoye field development will be increasing environmental degradation, which does not correspond to the idea of a green economy. Energy supply will be based, as before, on 
existing coal resources, which are necessary to supply local coal thermal power plants, both existing and under construction. Thus, along with pollution caused by ore mining and processing enterprise, growth of coal consumption will contribute to environmental degradation.

\section{Approaches to evaluation of economic growth perspectives}

Preliminary evaluation of environmental impact was realized for the ore field Ozernoye during 2012-2013 years expeditions. Some preparations to its exploitation (stripping works, pit construction) were completed in 2010, and a development of a lead and zinc concentrate's plants was preliminary planned to be completed in 2013. Field study, taken by the group of researchers and students of the Department of Environmental Management (MSU) in 2013 summer season showed that the plant is still in a projecting phase.

Process of production at any ore mining and processing enterprise contains such phase as milling of ores before transportation, which causes emissions of $\mathrm{NO}_{2}, \mathrm{CO}$, soot and other air pollutants. Planned volume of production and technological specifics of the Ozernoye field will lead to a number of natural landscape disturbance, including significant exceed of a maximum permissible concentration (MPC) of nitrogen dioxide and benz(a)pyrene at the boundary of Sanitary Protective Zone (SPZ). Land disturbance by pit and factories construction, accumulation of waste rock dumps, soil pollution, etc. will cause transformation of landscapes by changes in exogenous geological processes, parameters of hydrogeological and surface flows, increasing erosion processes, etc. According to project study, waste production is a significant risk factor: it is estimated that total volume of solid waste will reach more than 47 million tons, and the full restoration of disturbed areas will require 50 years.

Evaluation of possibilities to green regional economy has an interdisciplinary character, and requires an integrated approach with attention to economic, ecological and geographical factors. One of approaches, combining these aspects, is accounting of ecosystems' services. Recent scientific researches - both theoretical and applied works demonstrate relevance of a cost-benefit analysis for purposes of green growth at a regional level [20-23]. According to such researches, value of ecological services of natural systems is comparable to a market value of natural resources. Costs-benefits analysis for modern Russian economy at a regional level must be based on accounting of ecosystems services, including such indicators as intensity of energy flows in landscapes, carrying capacity of natural ecosystems, changes in terrestrial albedo coefficient due to land use structure and others [24]. In a case to define directions of green economic development, environmentally oriented activities, efficient from ecological point of view, will be priorities.

A large number of scientific publications in recent years have been devoted to evaluation of ecological services of natural systems to compare their value with the cost of natural goods. Many authors [24-26] conclude that benefits from the conservation of natural ecosystems greatly exceed the revenues from resource extraction - in most cases an excess depends only on the length of time perspective. Considering the case of Ozernoye ore field, we can conclude that changes in a land use will result in declining of landscape capacity to absorb green-house gases (GHG), including $\mathrm{CO}_{2}$.

Since the impact on the landscape is of local scale, and a land reclamation is obligatory part of works, there haven't to be significant irreversible changes in the landscape structure. Serious temporal risk is related to changes in properties of vegetation which can lead such repercussions as:

- Loss of extremely important ecological services of forests as a part of biogeochemical cycle (photosynthesis, oxygen producing, etc.);

- Increasing green-house gases emissions;

- Changes of albedo's coefficient and arising surface temperature; 
- Declining soil fertility at the surrounding lands;

- Reducing resources of medicinal and food plants;

- Changes in hydrological regime;

- Increasing fire risk.

Upon completion of construction the ore mining and processing enterprise "Ozernoye", the forest will be cut down at the area of direct influence - about 2,000 hectares. The annual carbon storage by forests of the Republic of Buryatia is estimated at 12.5 million tons [26]. The larch forests make a largest contribution (about 35\%) in this value. Since a larch is the main tree species in the Ozernoye field, we can state a significant reduction in the absorption of $\mathrm{CO}_{2}$ from deforestation. Preliminary calculations made by taking into account the average annual carbon sequestration of larch wood ( $0.43 \mathrm{t} / \mathrm{ha})$ suggests that the costs of deforestation in the area will result in an additional emissions of about 860 ton/year. Taking the cost of $1 \mathrm{t} \mathrm{CO}_{2}$ absorption equal to $\$ 10$, we can assess the total loss from the landscape deforestation as $\$ 8,600$. However, we consider physical indicators that some specialists suggest to focus [27], are more appropriate in this case.

In general, in a case of compliance with production standards and a fire safety's rules implementation, the impact on landscapes will not have irreversible consequences and a risk to local people will be limited by frame of an area of Ozernoye field allotment. In contrast, the development of the field Kholodninskoye would have serious environmental consequences for Lake Baikal. Thus, the development of Ozernoye field is a key element of social and economic policy of Buryatia, aimed to improve local standard of living, but it does not correspond to the ideas of a green economy.

\section{POSSIBILITIES FOR GREENING ECONOMY AT THE BAIKAL AREA}

Current policy on transition to a green economy in Buryatia is very inconsistent. On the one hand, the number of regional development's programs for 10-20 years ahead include aimed to greening economy, on the other - non-efficient "brown" economy goes by traditional way. For example, there still are single cases of renewable energy use within the Baikal area, and they do not constitute a unified system. At the same time the potential of, for example, solar energy in Buryatia is very high and was valued by experts as sufficient for its development (Fig. 4). There are real prospects for the use of other renewable energy sources, the potential of which is also high in the republic - resources of small hydro energetic, wind energy, waste of forest industry, etc. Evaluations of renewable energy sources are contained in the Strategy of the Development of the Fuel and Energy Complex of the Republic of Buryatia (Table 2), adopted by the government in 2009.

Specific measures to improve energy efficiency and the means to its implementation are listed in the Republic target program "Energy saving and improvement of energy efficiency in the Republic of Buryatia up to 2020". Total amount of financing from all the sources both public and private - is about 10 billion RR or $\$ 300 \mathrm{mln}$. Large number of activities, planned for all regions of Buryatia, identified in the program. Among them - modernisation of boiler-rooms and a heat-supply facilities; installation of solar collectors at the hospital and construction of wind farms (Eravninsky, Dzhidinsky and others areas).

There is some potential for green cooperation in Buryatia with neighbouring countries (China, Mongolia, Japan), such as a pilot project on producing biogas at the pig farm, or construction of processing plant for lumber waste, the funding for which will be provided by the Japanese company Mitsui. However, these cases are rather an exception to general situation. In the near future economic development in this region will be determined, in particular, the decision of the Russian government to develop the coal generation. In this regard, it is extremely important for the region to determine the most realistic ways of "green" development. 


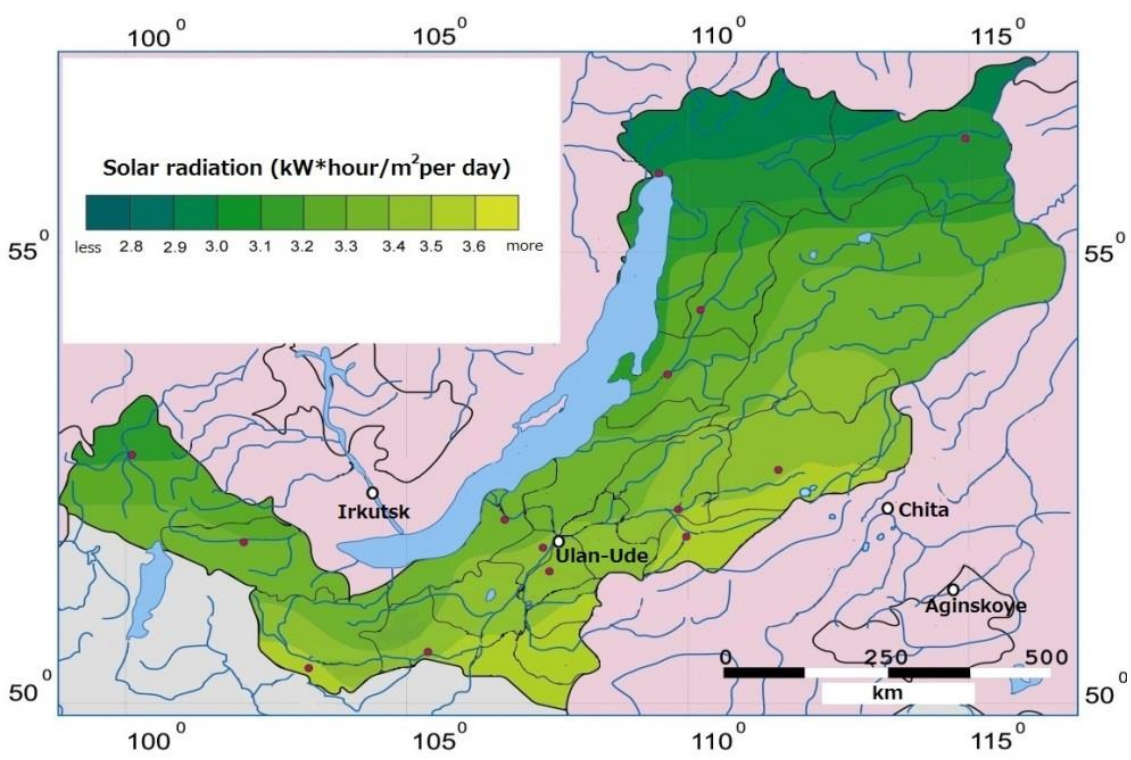

Figure 4. Total radiation on the level of territory of Buryatia [15]

The actual economic development causes environmental degradation and loss of ecological benefits. As it was shown after an analysis of the main prospective directions of the economy's development of Buryatia, a probability of transition to a "green" way in the sectors of mining and energy is currently quite low. Different situation is forming now in other sectors of the economy - particularly in the tourism industry, what is fully correspond with the ideas of "green" economy: 1) reducing ecological scarcities through saving environmental services of the unique natural landscapes; 2) reducing environmental risks by investing in a low-carbon economy; and 3) resulting in improved human well-being and social equity through "green" employment. Studies in this field reveal that new technologies, including that in a renewable energy, are more labour-intensive than fossil fuel-based energy generation, and contribute to increasing high-qualified labour [10].

Table 2. Resources of solar power of Buryatia [28]

\begin{tabular}{ccccccc}
\hline $\begin{array}{c}\text { Gross } \\
\text { potential, bn } \\
\text { ton of oil } \\
\text { equivalent } \\
\text { [toe] }\end{array}$ & $\begin{array}{c}\text { Heat } \\
\text { production, } \\
\text { [mln toe }]\end{array}$ & $\begin{array}{c}\text { Electricity } \\
\text { production, } \\
{[\text { mln toe }]}\end{array}$ & $\begin{array}{c}\text { Total, } \\
{[\mathrm{mln}} \\
\text { toe }]\end{array}$ & $\begin{array}{c}\text { Heat } \\
\text { production, } \\
{[\mathrm{k} \text { toe }]}\end{array}$ & $\begin{array}{c}\text { Electricity } \\
\text { production, } \\
{[\mathrm{k} \text { toe }]}\end{array}$ & $\begin{array}{c}\text { Total, } \\
{[\mathrm{k} \text { toe] }}\end{array}$ \\
\hline 52.7 & 343.6 & 21.9 & 365.5 & 33.2 & 0.8 & 34.0 \\
\hline
\end{tabular}

Special economic zone (SEZ) "Baikal haven" (Fig. 5) started to be built at the territory of the Republic of Buryatia, on the coast of the Lake Baikal in 2009. The basic principle of its development is a public-private partnership, in a frame of which it is planned to build transportation infrastructure, ski resorts and a number of hotels with modern systems of water supply and sewage systems, and other recreational facilities. SEZ development program aimed on creation of infrastructure that minimizes the impact on the natural landscape and meet all the environmental restrictions: nature conservation in this case is a practical necessity. In this regard, SEZ development program widely use approaches to energy saving, resources efficiency, etc. Special economic zone (SEZ) "Baikal haven" (Fig. 5) started to be built at the territory of the Republic of Buryatia, on the coast of the Lake Baikal in 2009. The basic principle of its development is a public-private partnership, in a 
frame of which it is planned to build transportation infrastructure, ski resorts and a number of hotels with modern systems of water supply and sewage systems, and other recreational facilities. SEZ development program aimed on creation of infrastructure that minimizes the impact on the natural landscape and meet all the environmental restrictions: nature conservation in this case is a practical necessity. In this regard, SEZ development program widely use approaches to energy saving, resources efficiency, etc.

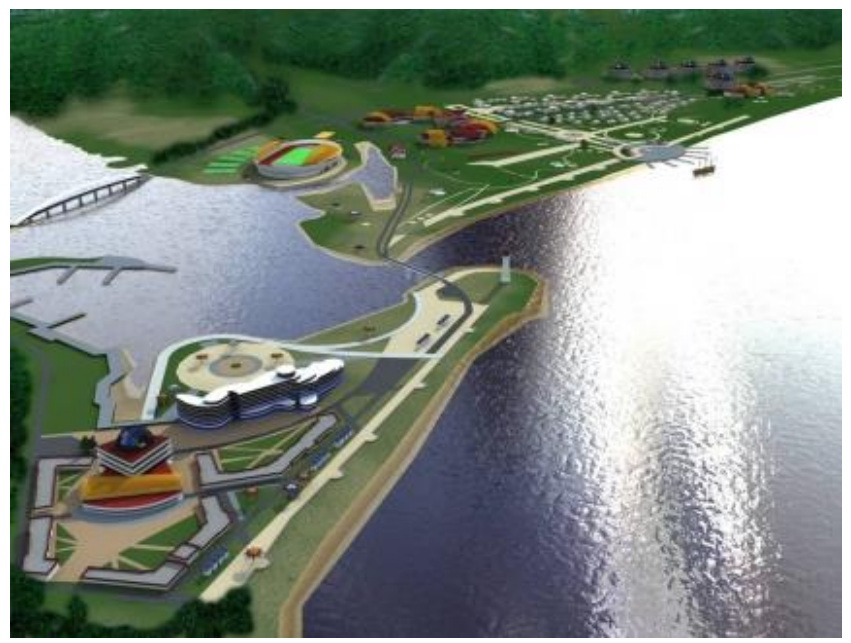

Figure 5. "Turka" plot at the Special Economic Zone "Baikal haven" (project)

In the republic target program "Energy saving and improvement of energy efficiency in the Republic of Buryatia up to 2020" [28] a number of measures in line of a green development at SEZ are proposed: a complex of energy-saving measures in the construction of the boiler plant and other facilities in the regions of Buryatia; the arrangement of wind turbines and solar collectors, etc. The overall effect of these activities will be 1.5 billion RR.

Table 3. Regional target program "Energy saving and energy efficiency in Republic of Buryatia up to 2020" (fragment)

\begin{tabular}{lcccccl}
\hline \multicolumn{1}{c}{ Energy saving in SEZ } & \multicolumn{7}{c}{ Amount of financing, mln RR } & \\
\cline { 2 - 6 } Period & Total & $\begin{array}{c}\text { Federal } \\
\text { budget }\end{array}$ & $\begin{array}{c}\text { Regional } \\
\text { budget }\end{array}$ & $\begin{array}{c}\text { Municipal } \\
\text { budget }\end{array}$ & $\begin{array}{c}\text { Extra } \\
\text { budgetary } \\
\text { sources }\end{array}$ & Effect \\
\hline Totally & 341.05 & 315.75 & 0.00 & 0.00 & 25.30 & $\begin{array}{l}\text { Effectivness } \\
\end{array}$ \\
2010 & 54.97 & 46.67 & 0.00 & 0.00 & 8.30 & 1.5 mln toe \\
$2013-2015$ & 144.71 & 127.71 & 0.00 & 0.00 & 17.00 & \\
$2016-2020$ & 0.00 & 0.00 & 0.00 & 0.00 & 0.00 & \\
\hline \multicolumn{7}{l}{ Renewable energy sources } \\
\hline
\end{tabular}

Intended common effect on the development of the SEZ "Baikal haven" for 2026 should be about 16 billion RR (or 320 mln EUR). In addition, there will be created more than 4 million of job places. However, tourism industry development will also result in a transformation of natural landscapes: construction of a ski resort on the Mount Bych'a requires of deforestation and will lead to disturbance of the landscape at the area of 2,340 ha. In contrast to mining activity at the ore fields, changes in a land use in this case are not so 
radical, and landscape's disturbance is fragmentary, that allow to save partially forested landscapes. Social effect from realisation of this project, which can be measured by employment increase, will be 4.1 thousand job places, and a volume of services will reach 30.9 bn RR, which is highest amount if compare with other clusters of SEZ. Undeniable advantage of this project is that, in addition to the development of ski tourism, it is also planned to develop ethnographic and religious tourism, based on the authentic culture of the local population. This undoubtedly will attract special attention to preservation of a pristine nature of the region. Thus, we can conclude that a general trend of the Tourism and Recreation Special Economic Zone "Baikal haven" will correspond to ideas of green economy. Further development of the SEZ can be regarded as a successful example of economy, which meets "green" standards, i.e. is directed on increase of living standards and preserving ecosystems.

\section{CONCLUSION}

The case of Baikal area is one of the typical for Russia. Today, there are first steps towards a green economy in the Republic of Buryatia. Unfortunately, a conservative approach continues to operate in general: traditional energy takes leading position in the regional energy balance. Such case we have considered by the example of the Ozernoye ore field. Environmental impact is accompanied there by changes in a land use structure, loss of environmental services and decrease of greenhouse gases absorption.

Despite that, there are successful cases of investment in a green economy in the Baikal area, one of which is the SEZ "Baikal haven". The region has established the necessary institutional preconditions for the development of green economy. Tourism industry development will contribute to preservation of ecological functions of the landscape and fully corresponds to the ideas of the green economy, such as reducing environmental risks by investing in a low-carbon economy and resulting in improved human well-being through "green" employment. Thus, there are sufficient natural and institutional prerequisites to build regional economy in a green way. Elaboration of more detailed recommendations on greening the economy of Buryatia in industrial sectors will be the subject of further researches.

\section{NOMENCLATURE}

\section{Abbrevations}

$\begin{array}{ll}\text { BNA } & \text { Baikal Natural Area } \\ \text { CEZ } & \text { Central Ecological Zone } \\ \text { GDP } & \text { Gross Domestic Product } \\ \text { GRP } & \text { Gross Regional Product } \\ \text { GHG } & \text { Green-house gases } \\ \text { MPC } & \text { Maximum Permissible Concentration } \\ \text { SEZ } & \text { Special Economic Zone } \\ \text { SPZ } & \text { Sanitary Protective Zone } \\ \text { TFP } & \text { Total Factor Productivity }\end{array}$

\section{REFERENCES}

1. World Bank Report «The Russian system of environmental management: the way of its modernization», Moscow, Center for environmental projects, 2009.

2. Asheim, G.B., Green National Accounting for welfare and sustainability, Scottish Journal of Political Economy, 50 (2), pp. 113-130, 2003., http://dx.doi.org/10.1111/1467-9485.5002001 
3. Brown, L., Progress Towards a Sustainable Society. World Watch Institute - State of the World, London: Earthscan, 2004.

4. Kennet, M. and Heinemann, V., Green Economics: setting the scene. Aims, context, and philosophical underpinning of the distinctive new solutions offered by Green Economics. Green Economics, 1 (1/2), pp. 68-102, 2006. , http://dx.doi.org/10.1504/IJGE.2006.009338

5. Isard, W., et al. Ecologic-economic analysis for regional development. The Free Press, USA. 1972.

6. Rexhepi, S., Sustainable Economic Growth: a Perspective for Macedonia, J. sustain.dev. energy water environ.syst., 1(3), pp. 272-280, 2013. http://dx.doi.org/10.13044/j.sdewes.2013.01.0020

7. Runsheng, Y., Minjuan, Zh., Ecological restoration programs and payments for ecosystem services as integrated biophysical and socioeconomic processes - China's experience as an example, Ecological Economics, 73, pp 56-65, 2012., http://dx.doi.org/10.1016/j.ecolecon.2011.11.003

8. Pakina, A., Environmental management and "green" economy: ecological and economic aspects of regulation. Environmental management: theory, practice, education. Ed. Prof. M.V. Slipenchuk. M.: MSU Faculty of Geography, pp. 98-106, 2012.

9. Frankhauser, S., Sehlleier, F. and Stern, N., Climate change, innovation and jobs, Climate Policy, 8(4), pp. 421-429, 2008., http://dx.doi.org/10.3763/cpol.2008.0513

10.Simos, M., Pacca, S., Socio-economic benefits of Wind Power in Brasil, J. sustain.dev. energy water environ.syst., 1(1), pp 27-40, 2013.

11. National Program "Environment Protection of the Russian Federation on period of 2012-2020". Ministry of natural resources and environment of the Russian Federation. http://www.mnr.gov.ru/upload/iblock/81d/gosprogramma2012_2020.pdf. [Accessed: 12-Mar-2014]

12.Lehr, U., Nitsch, J., Kratzat, M., Lutz, C. and Edler D. Renewable energy and employment in Germany, Energ.Policy, 36 (1), pp. 108-117, 2008., http://dx.doi.org/10.1016/j.enpol.2007.09.004

13.Russian Statistical Yearbook 2012. Moscow, Rosstat, 2012.

14.Buryatia State Authorities, Official portal: http://www.egov-buryatia.ru. [Accessed: 20-Aug-2013]

15.Strategy of Fuel-Energy Complex Development of the Republic of Buryatia up to 2030. Ulan-Ude, Ministry of Natural Resources of the Republic of Buryatia, 2008.

16.Protection of the Lake Baikal. Ministry of Natural Resources and Ecology of the Russian Federation, Official portal: http://mnr.gov.ru. [Accessed: 23-Aug-2013]

17. State report on the environment of the Republic of Buryatia. Ulan-Ude, Ministry of Natural Resources, 2011.

18.Tulokhonov, A. K., Slipenchuk, M.V., Dmitrieva, N. G., Development of the mining cluster in the Transbaikalia: problems and solutions. Geography and Natural Resources. Novosibirsk, “GEO”, 1, pp. 108-113, 2010.

19.Dmitrieva, N. G., Economic-geographical prerequisites of forming the mining cluster at the base of Eravna ore area, Ph.D. thesis, Ulan-Ude, 2011.

20.Reichhuber, A., Requate, T., Alternative use systems for the remaining Ethiopian cloud forest and the role of Arabica coffee - A cost-benefit analysis. Ecological Economics, 75, pp. 102-113, 2012., http://dx.doi.org/10.1016/j.ecolecon.2012.01.006

21.Kumar, P. and Muradian, R. Payment for Ecosystem Services, Oxford University Press, 2009.

22.Colombo, S., Calatrava-Requena, J. and Hanley N., Analysing the social benefits of soil conservation measures using stated preference methods, Ecological Economics, 58(4), pp. 50-61, 2006., http://dx.doi.org/10.1016/j.ecolecon.2005.09.010 
23.Pakina, A., Ecological economics as a science on limited resources. Problems of modern science, 7(3), Stavropol, Logos, pp. 163-169, 2013.

24.Gorshkov, S. P., Biosphere's Doctrine. Introduction. Moscow, Geographical faculty of the MSU, 2007.

25.Bobylev, S. N., Zubarevich, N. V., Soloviova, S. V., Vlasov, Yu. S., Sustainable development: methodology and methodic of dimension, Moscow: Economics, 2011.

26.Tulokhonov, A. K., Puntsukova, S. D., Skulkina, N. A., Kuznetsov, Yu. A., Contribution of the Buryatian forests in a balance of carbon storage and emissions. Geography and Natural Resources, Novosibirsk: "GEO”, No.2, pp. 41-48, 2006.

27.System of Environmental-Economic Accounting, Central Framework, White-cover publication, pre-edited text subject to official editing, United Nations, World Bank. 2012.

28.Republic target program "Energy saving and improvement of energy efficiency in the Republic of Buryatia up to 2020", Ulan-Ude, Ministry of Natural Resources of the Republic of Buryatia, 2010. 